\title{
カーボンブラックとピッチコークスを骨材とする 炭素材の摩擦特性の支配因子1)
}

(1998 年 4 月 16 日受理)

赤上順一*·尾崎純一十·大谷朝 男 $^{\dagger}$

摺動用炭素材料には低い摩擦抵抗が要求されるが, それと同時に耐摩耗性も求められる.これらの要 求を満足するためにピッチコークスとカーボンブラックの混合物を原料として用いた炭素系複合材料が 開発されている.しかし，製造現場に扔いて製品の物性值のばらつきか問題になっている．特に，摩擦 係数のばらつきは製品の歩留りの低下を招くため, 最も深刻な問題である. 本研究では, 機械用炭素材 料の摺動特性を支配する因子を見いだすため, 異なるロットの18 個の炭素ブロックを調製した．これ らの試料のかさ密度, ショア硬度, 曲げ強度抢よびヤング率を測定し, 物性值と摩擦係数の相関を検討 したところ相関は見られなかった，試料のX 線回折は 2 種の成分，すなわち黒鉛抢よび乱層構造から なることを見いだした．この回折図形を分離して求めた黒鉛成分の割合と摩擦係数の間には強い相関が あることがわかった. 結局, ピッチコークスとカーボンブラックからなる炭素ブロックの摺動特性は主 として材料中の黒鉛成分により支配されることが明らかになった.

\section{1 はじめに}

自己潤滑性は炭素材料が有する特性の一つである.しばしば引 用される潤滑の機構としては，黒鉛結晶を二つの動く面の間に置 いたときに，弱く結合した黒鉛層が滑るというものと党，摺動に よりはく離した黒鉛層がロール状になり，これがコロの役割を果 たすという機構とがある33. いずれの場合も黒鉛構造のゆるく結 合した層状構造が潤滑性発現のむとになっている．この特性を積 極的に活用した炭素製品が機械用(摺動用)炭素材であり，軸受け や真空ボンプ用ブレードなどに用いられている．通常の摺動用炭 素材は，ピッチコークスをたは人造黒鉛骨材をバインダーピッチ で混練した後, 成形, 炭素化, さらに場合によっては黒鉛化して 製造されている4)．ここで使用される原料はいずれむ高温処理に より結晶が成長しやすい “易黒鉛化性炭素”である.したがって $2800{ }^{\circ} \mathrm{C}$ 程度の高温で処理された炭素材は高結晶性を有し，その 結果優れた摺動特性を示すようになるが，同時に摩耗されやすく なる.

一方, カーボンブラックは数 $\mathrm{nm}$ の粒子であり, 高温処理して も“サイズ効果”により結晶成長の抑制されることが知られてい る5)。そこでピッチコークスとカーボンブラックを骨材に併用 し, 前者で高い摺動特性を, 後者で耐摩耗性を発現させる試みが 行われている4).ところが，この方法を製造現場で用いたところ

日立化成工業株式会社山崎工場(桜川)，316-0036 日立 市鮎川町 3-3-1

†群馬大学工学部材料工学科, 376-8515 桐生市天神町 1$5-1$
製品間の特性のばらつき，とりわけ実用上むっとも重要な特性で ある摩擦係数に大きなばらつきが現れ，歩留りの大幅低下をもた らすことが明らかになった．この摩擦係数のばらつきは測定の不 手際によるものというよりは, 製品そのものの物性のばらつきで あると考えている. 確かに摩擦俰数はその測定時の温度 ${ }^{6}$ や湿 度7などの䨌囲気，表面上の付着介在物の存在68) によって大き く変動し，測りにくいパラメーターである．よって実用的な観点 からは，摩擦係数と密接に相関する測定容易な物性值を見いた し，それにより品質管理を行う方が便利である．また，これまで 炭素材料の摺動特性は，その中に含まれる黒鉛成分に大きく依存 するとされてきたが9)，摩擦㐿数を支配する特性を明確にするこ とも，今後の製造過程改善の上で重要である.

本研究では原料を混練するロット(回分)は異なるが，その後の 調製条件は全く同じ試料について，摩擦係数とその他の物性を測 定しそれらの間の相関を把握すること, そしてこのシリーズの炭 素材料の摩擦係数を支配する因子を明らかにすることを目的とし た.

\section{2 実験}

2.1 試料

骨材には石炭系ピッチコークスとカーボンブラックの混合物 を, バインダーとしては石炭系硬ピッチと石炭系タールの混合物 を使用した．混合割合は重量比でピッチコークス：カーボンブラ ック：硬ピッチ：タール=1:1:1:1である.ついで混練機中で $280 \pm 20{ }^{\circ} \mathrm{C} て ゙$ 加熱, 混合しながら揮発分を調整した後(約 8 時 間), 油圧ブレスで約 $60 \mathrm{MPa}$ の圧力下で約 $250 \times 150 \times 80 \mathrm{~mm}^{3}$ 
のサイズに冷間加圧成形し，18 個の混練ロットの異なる試料を 調製した．ついでこれらの試料を同時にコークス粉中に入れ，昇 温速度 $1-5{ }^{\circ} \mathrm{Ch}^{-1}$ で最高温度 $900{ }^{\circ} \mathrm{C}$ まで昇温し，その温度で $10 \mathrm{~h}$ 保持して炭素化した。最後に炭素化試料をアチソン炉に移 し，約 $2800{ }^{\circ} \mathrm{C}$ で $5 \mathrm{~h}$ 黒鉛化処理を行ったこの二つの熱処理に 用いた炉の温度分布は既知であり，熱処理は温度分布の影響の少 ない位㯰で行った。

\section{2 測 定}

得られた黒鉛化試料の中心部から $10 \times 10 \times 50 \mathrm{~mm}^{3}$ の試片を切 り出し，以下の測定に供した．かさ密度は寸法と重量とから算出 し，電気抵抗はホイートストンブリッジ法により測定した。曲げ 強さはオートグラフ試験機を用いて 3 点曲げ法により測定した (スパンの大きさ : $40 \mathrm{~mm}$, 加圧速度 : $2.3 \mathrm{~mm} \mathrm{~min}^{-1}$ ). ショア 硬度は JISZ7727 規定の D 型ショア硬度計で測定し，また弾性 係数は固有振動数とかさ密度, 試片長さから次式を用いて算出し た

$$
E=\left(L^{2} f^{2} d\right) / 24.5
$$

ここで $E$ : 弾性係数, $L$ : 試片長さ, $f:$ 固有振動数, $d:$ かさ密度 である.摩擦係数は Fig. 1 に示した電動機入力差法 ${ }^{10)}$ で測定し た．スリップリングの回転数を $1500 \pm 5 \mathrm{rpm}$ に調節し，空回転 時とサンプル装着時の入力電力量差から次式で算出した.

$$
\mu=\left[\left(E I-E_{0} I_{0}\right)-R\left(I^{2}-I_{0}^{2}\right)\right] / 9.8 P V
$$

ここで $\mu$ : 摩擦係数, $E$ : 試片装着時の電圧, $I$ : 試片装着時の電 流, $E_{0}$ : 空回転時の電圧, $I_{0}$ : 空回転時の電流, $R$ : 電動機抵抗, $P$ : 試片装着力, $V:$ スリップリング周速である. 右辺分母中の

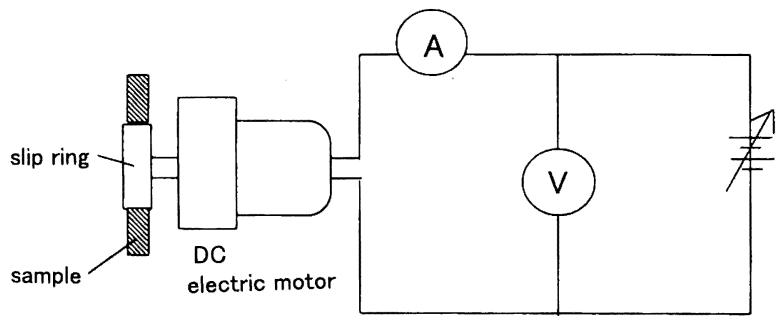

(a)

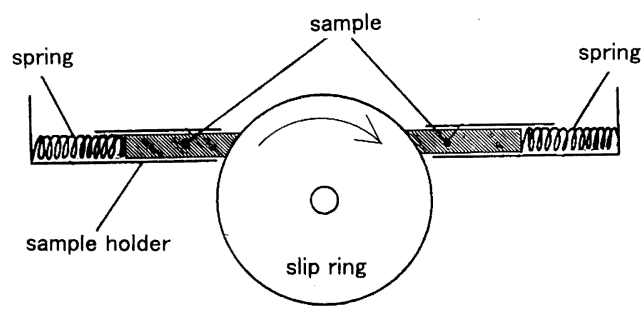

(b)

Fig. 1 A schematic representation of the apparatus used for the friction coefficient measurement.

(a): The electric circuit, (b): the detailed diagram of the front view around the sample.
9.8の值はワット変換係数で，単位は $\mathrm{kg} \mathrm{m} \mathrm{s}^{-1}$ である．上記の特 性はいずれも生産現場で日常行われている試験である．炭素材の 結晶構造の解析にはX線回折を用い, 学振法に準拠して行っ た

\section{3 結果と考察}

\section{1 特性値のばらつき}

今回試作したサンプルの摩擦係数の分布を Fig. 2(a)に示す. $\mu=0.1$ と0.4 付近にピークをむつ二峰性の分布を示すことが特徵 である.ちなみに $\mu=0.1$ の低い方のピークは製品の許容範囲内 $(\mu<0.3)$ にあるが, $\mu=0.4$ 高い方のピークはその範囲外にあ り, 約半数弱のサンプルが規格を满たしていないことになる.こ れが歩留りの低下の原因となっている.

Fig. 2(b)にかさ密度の分布を示す. サンプルの点数は少ないが, $1.75 \mathrm{~g} \mathrm{~cm}^{-3}$ にピークをむつ正規分布に近い形を示している. そ の他の物性値, 曲げ強さ, ショア硬度, 弾性俰数も類似の形を示 した.

\section{2 摩擦係数と他の特性との関係}

摩擦係数 $\mu$ は $F$ を摩擦力, $P$ を接触面間の垂直荷重とすると (1)式で与えられる6)

$$
\mu=F / P
$$

乾燥摩擦理論には凸凹説と凝着説がある ${ }^{8)}$. 現在主流となってい る後者によれば， $F$ は凝着による摩擦力 $F_{\mathrm{a}}$ と掘り起こしの摩擦 力 $F_{\mathrm{P}}$ の和として表わされる.ここで $F_{\mathrm{P}}$ は $F_{\mathrm{a}}$ に比べて非常に小
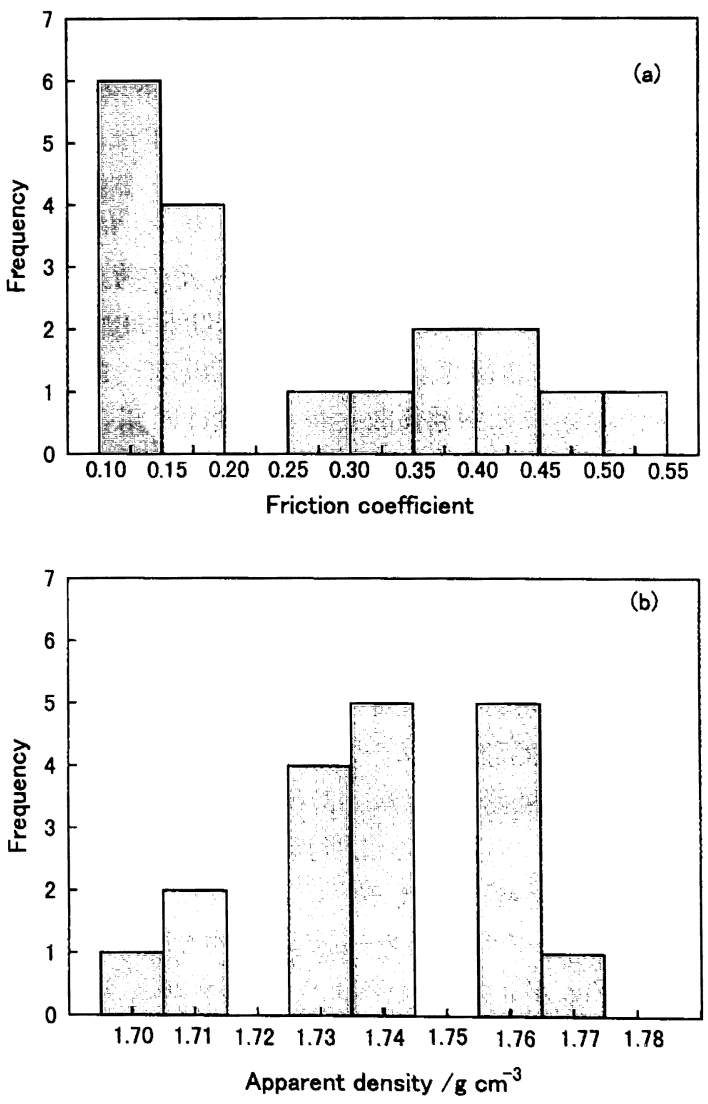

Fig. 2 Distribution functions of the samples prepared in this study.

(a): Friction coefficient, (b): apparent density. 

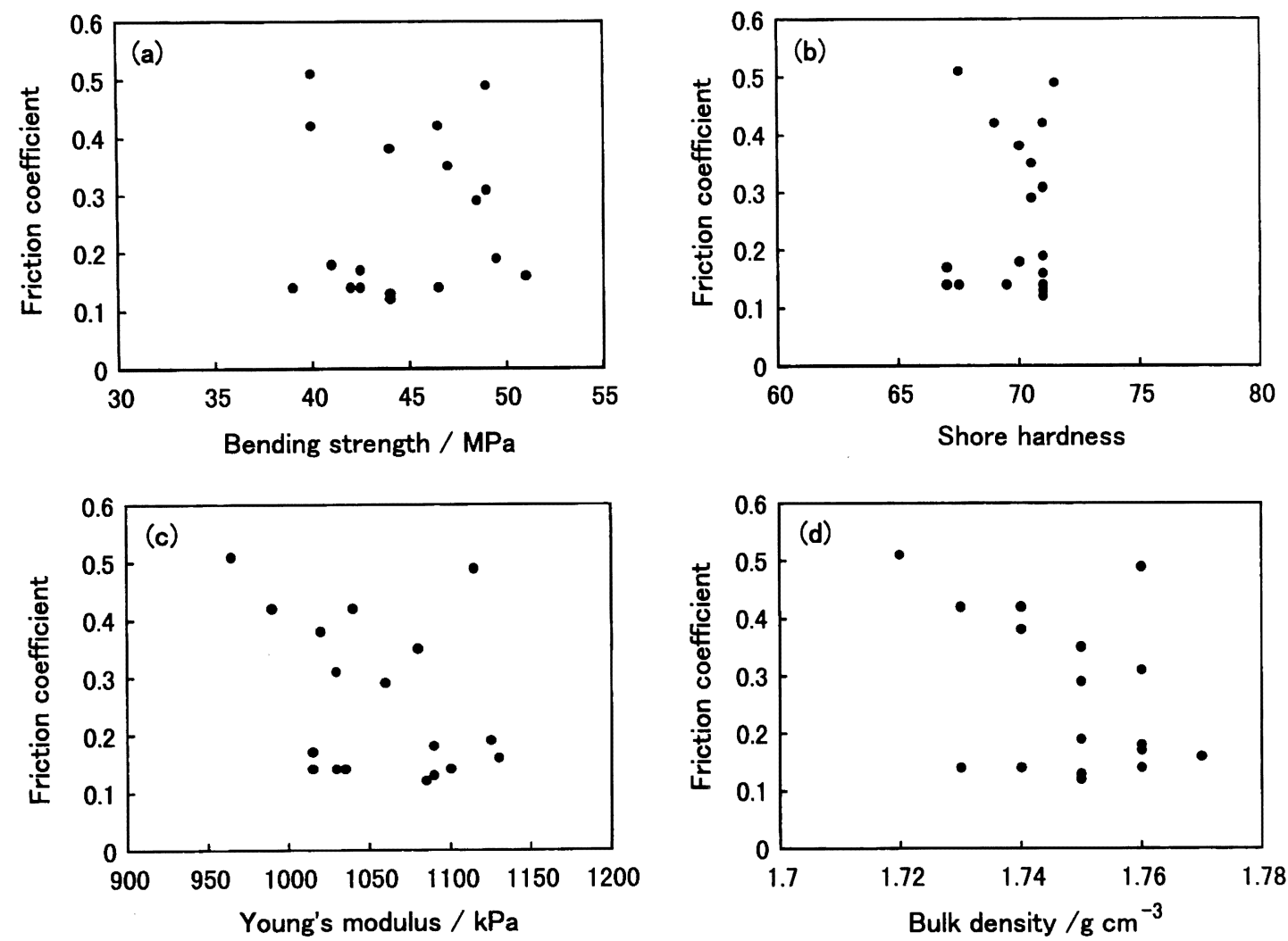

Fig. 3 Relations between several properties and the friction coefficient.

(a): Bending strength, (b): Shore hardness, (c): Young's modulus, (d): bulk density.

さく無視できるので8)，F=F $F_{\mathrm{a}}$ とおくことができる． $F$ は実接触 面積 $A$ に生じた凝着をせん断する力であり，その部分のせん断 強さを $S$ とすると,

$$
F=F_{\mathrm{a}}=S A
$$

さらに, $\mu=S A / P$

となる. 本研究で用いた摩擦力の測定法は一定の荷重下で行うた め, (3)式中の $P$ は一定である.つまり $\mu$ は $S$ および $A$ に比例 すると考えられる. 本研究で測定した物性の中で，曲げ強さと硬 度は $S$ を通して，また弾性係数とかさ密度は組織の緻密さと関 係するので $A$ を通して摩擦係数に関係すると考えられる. そこ でこれらの物性值と摩擦係数との関係を求めて Fig. 3 に示した. 図から明らかなように，いずれの場合も相関係数は小さく，曲げ 強さ, 硬度, 弾性率, かさ密度などの特性は摩擦係数の主要な支 配因子でないことがわかる.

\section{3 摩擦係数と黒鉛結晶化度の関係}

Fig. 4(a)に黒鉛化処理したカーボンブラックのX 線回折図形を 示す.この場合，黒鉛構造の(002)反射に相当する回折線は 2 $\theta=26.1^{\circ}$ に位置し, いわゆる乱層構造炭素 (turbostratic structure，以後 $\mathrm{T}$ 成分と略）である ${ }^{12)}$ 。これに対して石炭系ピッチコ 一クス，石炭系ピッチ拉よびタールの混合物を同様に処理した試 料の回折線は Fig. 4(b)でみられるように $2 \theta=26.4^{\circ}$ に位置し, 黒 鉛構造に近い成分 (graphitic structure, 以後 $\mathrm{G}$ 成分と略)であ る.いずれの場合も回折線は複合図形ではなく，炭素試料が単一 相で構成されていることがわかる.

Fig. 4(c) と(d)は摩擦係数の大きな試料と比較的小さな試料の X 線回折図形の一例である. いずれの回折線も $2 \theta=26.1^{\circ}$ と $26.4^{\circ}$
に位直する二つの回折線からなる複合図形を示し，炭素材が T 成分と G 成分とから構成されていることがわかる．しかし T, G 成分の回折強度比は両試料間で大きな相違がある. 本研究ではこ れらの相違を定量的に扱う一つの方法として，得られた複合回折 図形を Fig. 5 で示したように $\mathrm{T}, \mathrm{G}$ 両成分に分離して ${ }^{13)}$ ，面積比 より $\mathrm{G}$ 成分の分率 $f_{\mathrm{G}}=A_{\mathrm{G}} /\left(A_{\mathrm{G}}+A_{\mathrm{T}}\right)$ を求めた. Fig. 6 にこうし て求めた $f_{\mathrm{G}}$ と摩擦係数の関係を示した. $f_{\mathrm{G}}$ の小さな領域に抢け る摩擦俰数には若干のばらつきが見られるが，約 $8 \%$ までの $f_{\mathrm{G}}$ の増加に伴って摩擦係数は減少し，それ以上の $f_{\mathrm{G}}$ に颃いては一 定となった．摩擦係数 $\mu$ が $f_{\mathrm{G}}>8 \%$ 一定値を示すのは，この $f_{\mathrm{G}}$ の值で摺動面が $\mathrm{G}$ 成分でほぼ覆い尽くされ，これ以上 $\mathrm{G}$ 成分 が存在しても摩擦係数には影響しないためと考えられる. 以上, ピッチコークスとカーボンブラックからなる炭素ブロックの摺動 特性は主として材料中の黒鉛成分により支配されることが明らか になった.

最後に，製品製造上克服しなければならない問題を指摘してお く．つまり，Fig. 6 に示したデータは混練ロットの異なる原料混 合物より同条件で焼成したサンプルのものであるが， $f_{\mathrm{G}}$ の值， つまり黒鉛構造の発達の程度に大きなばらつきがあることであ る.この $f_{\mathrm{G}}$ が変動する理由として, 次の三つが可能な説明とし て考えられる. 一つは, カーボンブラックが他の共存成分の炭素 化過程を修飾し，結晶成長を抑制するという考え方 ${ }^{14)}$ である. 例えばカーボンブラックの含酸素表面官能基によるパインダーピ ッチへの影響が考えられる．もう一つは金属不純物による触媒黒 鉛化作用 ${ }^{15)}$ である、ニッケルや鉄等の金属の分散状態により生 成炭素の構造を無定型から黒鉛まで幅広く変えうることが知られ 


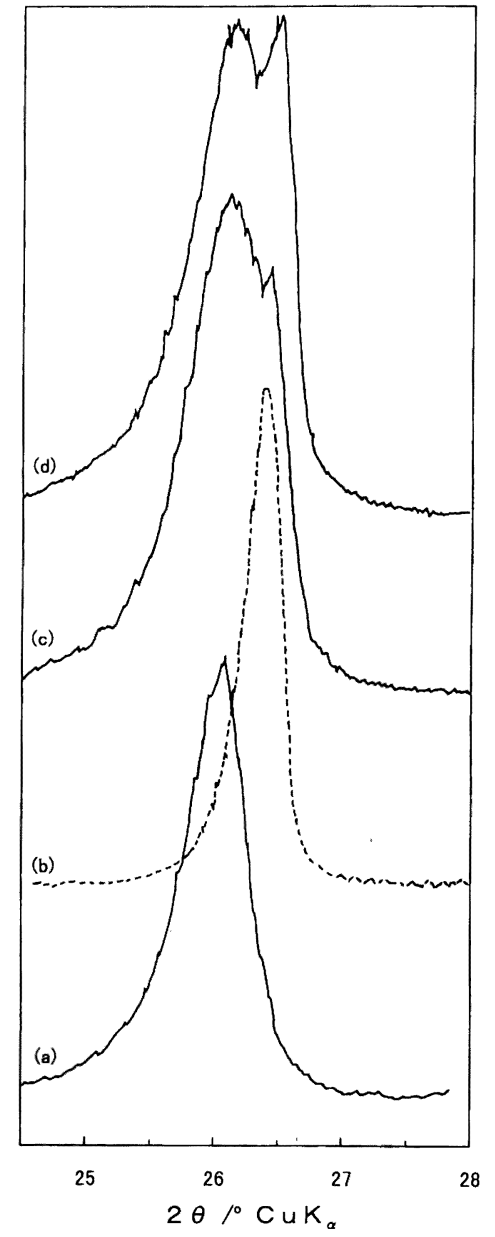

Fig. 4 X-Ray diffractograms of the carbons heat treated at $2800{ }^{\circ} \mathrm{C}$.

(a) and (b) are the carbon black and the pitch coke, respectively. (c) and (d) show typical diffractograms of the samples prepared in this study.

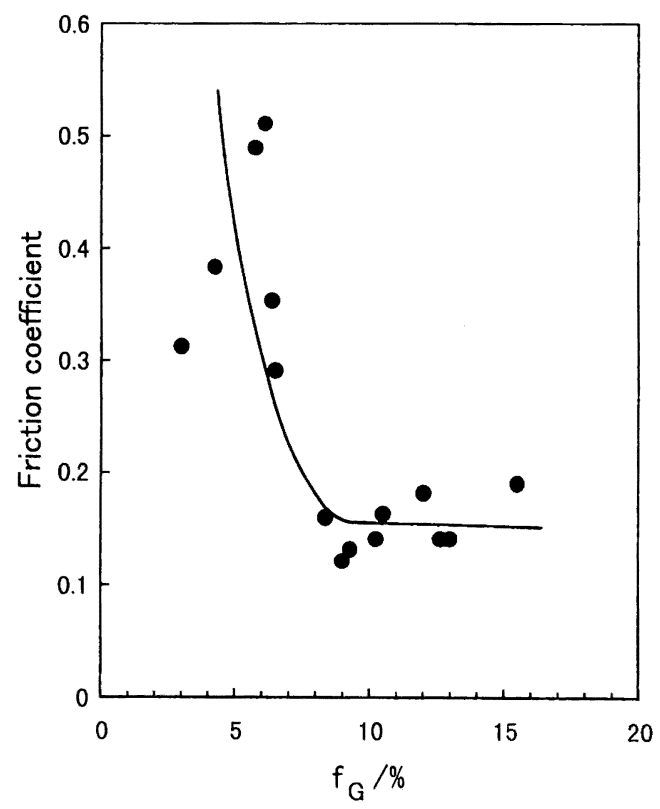

Fig. 6 Relation between friction coefficient and fraction of the graphitic component, $f_{\mathrm{G}}$.

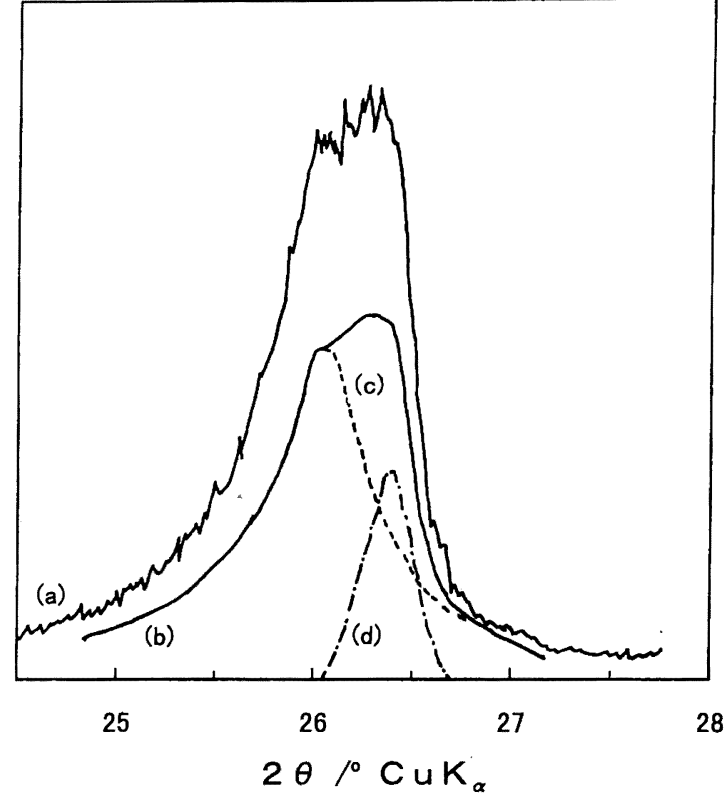

Fig. 5 Explanation of the peak separation used in this study.

The observed diffractogram (a) was firstly corrected according to the Gakushin (JSPS) method (b). The turbostratic component diffraction, (c) was subtracted from (b) to give the graphitic component (d). The parameter $f_{\mathrm{G}}$ was defined as the fraction of the peak areas of the graphitic component (d) to the whole diffraction (b).

ている. 本研究の場合，金属の混入は原理的には考えにくいが, 製造過程のどこかで混入することも可能性としてないわけではな い. 第三の可能な説明としては，原料の混合状態の制御が現場の 熟練作業者の経験に基づいて行われて抢り，その判断が変動しう ることである，混合状態を計測する技術も現在併用されている が，最終的な混練の終点判定，つまり混合物の流動性がなくなる 時点を判定することは技術者の経験に頼っており，定量的な規準 がないためである. 現在この因子の影響，つまり混練の工程がこ の黒鉛構造の出現に影響を及ぼすのではないかと考え，その観点 からの検討を行っている.

1）この報文を“炭素摺動材の特性改善に関する研究(第 1 報)”とする.

2）例えば，F. P. Bowden, D. Tabor，曽田範宗訳 “固体の摩 擦と潤滑”，丸善(1961)。

3) W. Bollmann, J. Spreadborough, Nature, 186, 29(1960).

4）松尾寬二，炭素，1977, 138.

5）仲田俊夫, “改訂炭素材料入門”, 炭素材料学会 (1984),p. 175.

6) F. P. Bowden, Proc. R. Soc. London, Ser. A, 212, 440 (1952).

7）松永正久監修, “固体潤滑ハンドブック”, 幸書房(1982).

8) F. P. Bowden, J. E. Young, G. Rowe, Proc. R. Soc. London, Ser. A, 212, 485(1952).

9) 奥山聖一, 炭素材料学会編, “新・炭素材料入門”, リア ライズ社(1996), p. 195.

10）出崎征夫, 炭素材料学会編, “電機用ブラシとその使い 方”, 日刊工業新聞社(1976), p. 41 .

11）稲垣道夫, 炭素材料学会編, “炭素材料実験技術 1 ”, 科学 
技術社(1978), p. 55 .

12) B. E. Warren, J. Chem. Phys., 9, 551(1934).

13) S. Otani, A. Oya, J. Akagami, Carbon, 13, 353(1975).
14) I. Mochida, K. Amamoto, K. Maeda, K. Takesita, Fuel, 56, 49(1977).

15) A. Oya, H. Marsh, J. Mater. Sci., 17, 309(1982).

\title{
Factors Controlling the Frictional Property of Carbon Blocks Containing Carbon Black and Pitch Coke as Fillers
}

\author{
Jun-ichi AKAGAMI ${ }^{*}$, Jun-ichi OzAKI ${ }^{\dagger}$ and Asao OYA ${ }^{\dagger}$ \\ Yamazaki Works (Sakuragawa), Hitachi Chemicals Co., Ltd.; 3-3-1, Ayukawa-cho, \\ Hitachi-shi 317-0036 Japan \\ †Department of Chemistry, Faculty of Engineering, Gunma University; Tenjin-cho, \\ Kiryu-shi 376-8515 Japan
}

Carbon materials for mechanical sliders are usually manufactured from a blend raw material, which consists of pitch coke and carbon black to optimize the lubricating character and the resistance to wearing. However, in the production of the materials in commercial, scattering in the properties of carbons has been introduced by employing this technique, above all the scattering in the friction coefficient is a serious problem leading to a reduction in the product yield. In order to understand the factor determining the lubricating properties of mechanical carbon materials, eighteen carbon blocks were prepared in separate batches. Their properties including bulk density, Shore hardness, bending strength, and Young's modulus were measured and no correlation was found between the friction coefficient and these properties. The X-ray diffractograms of the samples were found to consist of two contributions, i.e. graphitic one and turbostratic one. Inspection of the relation between the friction coefficient and the fraction of the graphitic component calculated from X-ray diffractograms revealed a strong correlation between these two parameters. The frictional property of the carbon blocks containing carbon black and pitch coke was revealed to be mainly controlled by the presence of the graphitic component. 